\title{
Quaternary fluvial environments in NE Morocco inferred from geochronological and sedimentological investigations
}

\author{
Melanie Bartz \\ Institute of Geography, University of Cologne, Cologne, Germany \\ Correspondence: Melanie Bartz (m.bartz@uni-koeln.de) \\ Relevant dates: $\quad$ Published: 25 January 2019
}

How to cite: $\quad$ Bartz, M.: Quaternary fluvial environments in NE Morocco inferred from geochronological and sedimentological investigations, E\&G Quaternary Sci. J., 68, 1-4, https://doi.org/10.5194/egqsj-68-12019, 2019.

Supervisors: Helmut Brückner, Olaf Bubenzer

and Gilles Rixhon

Dissertation online:

https://kups.ub.uni-koeln.de/7993/

The investigation of fluvial archives in NE Morocco is of high interest for unravelling palaeoenvironmental changes linked to Quaternary climate fluctuations, long-term tectonic activity and/or human influence in NW Africa. The prehistoric site of Ifri n'Ammar is situated in NE Morocco (Fig. 1) and represents a key location for deciphering the history of anatomically modern humans (AMHs) in northern Africa because it reveals Middle and Late Palaeolithic occupation phases since $\sim 170 \mathrm{ka}$ (Moser, 2003; Nami and Moser, 2010, Richter et al., 2010; Klasen et al., 2018; Fig. 2). This study uses two fluvial systems of different nature - the ephemeral stream Wadi Selloum and the perennial Moulouya River (Fig. 1) - in order to reconstruct the varying environmental conditions for the last $\sim 170 \mathrm{kyr}$, the time when AMH started to disperse into the region.

Both fluvial systems provide valuable insights into the geomorphic evolution of the region. It could be demonstrated that both responded to different environmental triggers: the small catchment of the Wadi Selloum $\left(\sim 290 \mathrm{~km}^{2}\right)$ is highly affected by the sensitive ecosystem of the Mediterranean region. This ephemeral stream is characterised by a discontinuous and heterogeneous sediment record (Fig. 1a) caused by short-term climatic shifts and human influence (Bartz et al., 2015, 2017). In contrast, the terrace record of the lower Moulouya was considerably affected by tectonic processes related to the collision between the African and Eurasian plates. A W-E-striking thrust fault, associated with $\mathrm{N}-\mathrm{S}$ compressive shortening in this region, could be identified; it strongly deformed the late Neogene sedimentary sequence of the lowermost basin drained by the Moulouya (Fig. 1) (Rixhon et al., 2017). While long-lasting aggradation led to the formation of composite fill terraces several tens of metres thick in the footwall reach (Triffa plain; Fig. 1b), a terrace staircase with at least three distinct terrace levels characterises the hanging wall reach (Ouled Mansour plateau; Fig. 1c). Tectonic activity appears thus to be the main driver for the evolution of the lower Moulouya terraces (Rixhon et al., 2017; Bartz et al., 2018).

Establishing chronostratigraphies of river sedimentary sequences always remains challenging. However, fluvial deposits of the Wadi Selloum could be well dated via optically stimulated luminescence (OSL) of quartz and post-infrared infrared stimulated luminescence of K feldspar. Although an independent age control was not possible, inter-method comparisons with thermoluminescence (TL) dating of a pottery shard (Bartz et al., 2015) and OSL and post-infrared infrared dating of two samples from the same sedimentary unit (Bartz et al., 2017) allowed the establishment of robust chronologies of the ephemeral stream deposits. The ages range between 

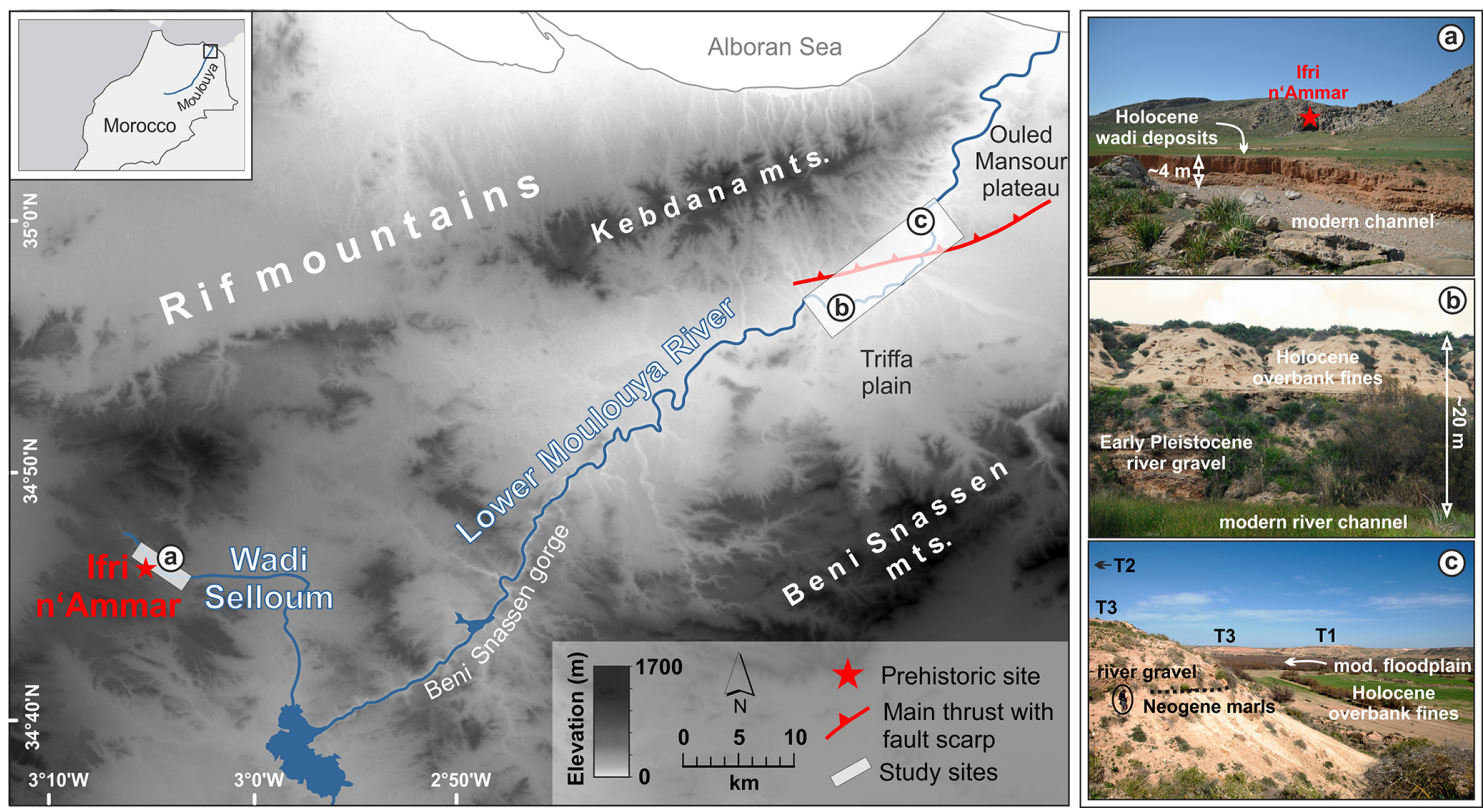

Figure 1. Relief map (based on ASTER Global DEM) of the lower Moulouya catchment including the two study areas (greyish rectangles) of the Wadi Selloum and the $\sim 20 \mathrm{~km}$ long investigated river reach of the Moulouya River. The red star denotes the prehistoric site of Ifri n'Ammar. (a-c) Images of the study areas. (a) Ephemeral stream Wadi Selloum in the direct vicinity of Ifri n'Ammar with up to $5 \mathrm{~m}$ high Holocene overbank fines (view towards the SE). (b) Footwall reach of the thrust zone showing stacked fluvial terraces of the Moulouya with Early Pleistocene gravel deposits and Holocene overbank fines (view towards N). (c) Hanging wall reach characterised by a well-preserved staircase of up to three Pleistocene Moulouya terraces above Holocene overbank fines and the modern floodplain. A clear unconformity (dashed line) between Neogene marls and Pleistocene river gravel is illustrated. Person for scale (ellipse) (view towards the NE).

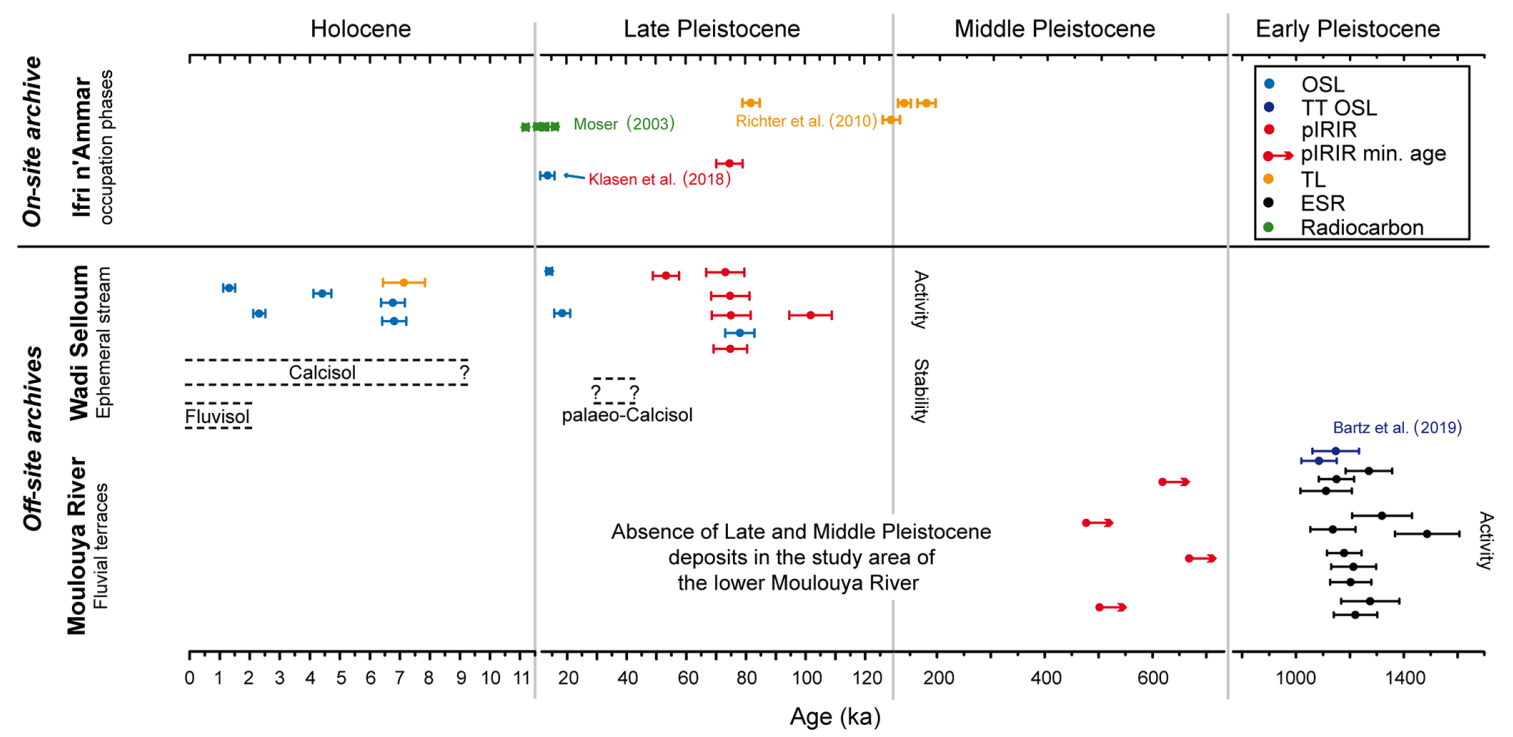

Figure 2. Chronological correlation between the on-site archive (occupation phases of the rock shelter Ifri n'Ammar) and the off-site archives (ephemeral stream deposits of Wadi Selloum and fluvial terrace deposits of the lower Moulouya). Chronological data of the two fluvial systems are based on optically stimulated luminescence (OSL), thermoluminescence (TL) (see Bartz et al., 2015), thermally transferred OSL (TT OSL) (see Bartz et al., 2019), post-infrared infrared stimulated luminescence and electron spin resonance (ESR) dating (see Bartz et al., 2017, 2018). From these results, phases of morphodynamic activity and stability can be deduced. The chronological framework of the prehistoric site of Ifri n'Ammar is based on radiocarbon (Moser, 2003) and luminescence dating (Richter et al., 2010; Klasen et al., 2018). 
$102 \pm 8$ and $1.3 \pm 0.2 \mathrm{kyr}$; they highlight the discontinuous fluvial deposition between MIS 5c and the Holocene (Fig. 2).

Due to the expected Early to Middle Pleistocene age of the fluvial terraces of the lower Moulouya it was challenging to establish luminescence chronologies. Quartz and $\mathrm{K}$ feldspar luminescence signals of the studied deposits had reached saturation, suggesting fluvial deposition at least as early as the Middle Pleistocene (Bartz et al., 2018; Fig. 2). However, electron spin resonance (ESR) dating offered a useful alternative way to gain further chronological information. Based on the multiple-centre approach in fluvial environments (Duval et al., 2015), aluminium (Al) and titanium (Ti) centres were measured in quartz; this was cross-checked with palaeomagnetic analyses (Bartz et al., 2018). Thus, a robust geochronological framework was established for the fluvial terraces, with numerical ages dating back to the Early Pleistocene and ranging between $\sim 1.5$ and $\sim 1.1 \mathrm{Ma}$ (Bartz et al., 2018) (Fig. 2). Recently, Bartz et al. (2019) additionally applied thermally transferred (TT) OSL on the same strata. The single-grain TT OSL results matched well with the newly established ESR chronology and proved the lower Quaternary (Calabrian) age of the fluvial terraces (Bartz et al., 2018, 2019).

Bearing in mind that chronostratigraphies of the ephemeral stream deposits and of the pre-Holocene Moulouya fluvial terraces do not yet exist, the application of different trapped charge dating techniques in combination with palaeomagnetic research served as a valuable tool to obtain chronological information about the deposition in the different fluvial systems.

In addition to using numerical and relative dating techniques, sedimentological, geochemical, mineralogical and micromorphological analyses have been carried out to distinguish periods of enhanced flooding-aggradation from periods of relative stability favourable for pedogenesis. The Wadi Selloum gives information about morphodynamic phases in the time of the settling of AMH (Fig. 2): periods of enhanced aggradation occurred around $\sim 100, \sim 75$ and $\sim 55 \mathrm{ka}$, after the Last Glacial Maximum, and during the Holocene, whilst sedimentation ended after $\sim 1.3 \mathrm{ka}$. Pedogenesis may be used as an environmental indicator for more humid climate conditions during MIS 3 (palaeo-Calcisol), the early Holocene (Calcisol) and the late Holocene (Fluvisol) (Fig. 2).

Although palaeoenvironmental implications should be taken with caution due to the discontinuity of the ephemeral stream system, it appears that more humid and warmer climate conditions may have favoured human settling in this area. This study thus provides the first insights into the palaeoenvironmental changes around the prehistoric site of Ifri n'Ammar during the last glacial-interglacial cycle. In contrast, the absence of Middle and Late Pleistocene deposits in the sedimentary record (Fig. 2) of the lower Moulouya seems to rule out climate as the main driver for long-term fluvial evolution in that region at least during the lower Qua- ternary. However, it provides valuable information on the regional tectonic history in NE Morocco (Bartz et al., 2018).

Data availability. The data are not deposited in data repositories, but are published in the articles Bartz et al. (2015), (2017), (2018) and (2019).

Acknowledgements. This research is affiliated with the CRC 806 "Our way to Europe", which is funded by the German Research Foundation (DFG; grant no. SFB 806/2). The support from the "Institut National des Sciences de l'Archéologie et du Patrimoine du Maroc" (INSAP), especially Abdeslam Mikdad at Rabat, and by the "Commission for Archaeology of Non-European Cultures" (KAAK), especially Josef Eiwanger, of the German Archaeological Institute (DAI) is gratefully acknowledged. Furthermore, my sincere thanks go to Mathieu Duval (Griffith University, Australia, and CENIEH, Spain), without whose support this research could not have been successfully completed.

\section{References}

Bartz, M., Klasen, N., Zander, A., Brill, D., Rixhon, G., Seeliger, M., Eiwanger, J., Weniger, G.-C., Mikdad, A., and Brückner, H.: Luminescence dating of ephemeral stream deposits around the Palaeolithic site of Ifri n'Ammar (Morocco), Quat. Geochronol., 30, 460-465, https://doi.org/10.1016/j.quageo.2015.02.012, 2015.

Bartz, M., Rixhon, G., Kehl, M., El Ouahabi, M., Klasen, N., Brill, D., Weniger, G.-C., Mikdad, A., and Brückner, H.: Unravelling fluvial deposition and pedogenesis in ephemeral stream deposits in the vicinity of the prehistoric rock shelter of Ifri n'Ammar (NE Morocco) during the last $100 \mathrm{ka}$, Catena, 152, 115-134, https://doi.org/10.1016/j.catena.2016.12.007, 2017.

Bartz, M., Rixhon, G., Duval, M., King, G. E., Álvarez Posada, C., Parés, J. M., and Brückner, H.: Successful combination of electron spin resonance, luminescence and palaeomagnetic dating methods allows reconstruction of the Pleistocene evolution of the lower Moulouya river (NE Morocco), Quaternary Sci. Rev., 185, 153-171, https://doi.org/10.1016/j.quascirev.2017.11.008, 2018.

Bartz, M., Arnold, L. J., Demuro, M., Duval, M., King, G. E., Rixhon, G., Álvarez Posada, C., Parés, J. M., and Brückner, H.: Single-grain TT-OSL dating results confirm an Early Pleistocene age for the lower Moulouya River deposits (NE Morocco), Quaternary Geochronol., 49, 138-145, https://doi.org/10.1016/j.quageo.2018.04.007, 2019.

Duval, M., Sancho, C., Calle, M., Guilarte, V., and Penna-Monné, J. L.: On the interest of using the multiple centre approach in ESR dating of optically bleached quartz grains: Some examples from the Early Pleistocene terraces of the Alcanadre River (Ebro basin, Spain), Quaternary Geochronol., 29, 58-69, 2015.

Klasen, N., Kehl, M., Mikdad, A., Brückner, H., and Weniger, G.C.: Chronology and formation processes of the Middle to Upper Palaeolithic deposits of Ifri n'Ammar using multi-method luminescence dating and micromorphology, Quatern. Int., 485, 89$102,2018$. 
Moser, J.: La grotte d'Ifri n'Ammar. Tome 1. L'Ibéromaurusien. AVA-Forschungen Band 8, Kommission für Allgemeine und Vergleichende Archäologie des Deutschen Archäologischen Instituts, Köln, 2003.

Nami, M. and Moser, J.: La grotte d'Ifri n'Ammar, Le Paléolithique moyen, Forschungen zur Archäologie Außereuropäischer Kulturen, 9, Reichert Verlag, Wiesbaden, 2010.

Richter, D., Moser, J., Nami, M., Eiwanger, J., and Mikdad, A.: New chronometric data from Ifri n'Ammar (Morocco) and the chronostratigraphy of the Middle Palaeolithic in the Western Maghreb, J. Hum. Evol., 59, 672-679, 2010.
Rixhon, G., Bartz, M., El Ouahabi, M., Szemkus, N., and Brückner, H.: Contrasting terrace systems of the lower Moulouya river as indicator of crustal deformation in NE Morocco, J. Afr. Earth Sci., 126, 45-57, 2017. 